\title{
Characterization of water and sludge produced from different designed clarifiers, case study.
}

Ahmed A.M. Afifi', Ayman M. M. Sawan ${ }^{2}$, Nashwa H.M. Rizk' ${ }^{1}$ and Ibrahim E. Mousa ${ }^{1 *}$

1Department of Environmental Biotechnology, Genetic Engineering and Biotechnology Research

Institute, University of Sadat City, Menofiya, 22857 Egypt.

${ }^{2}$ Chemistry Department, Alghad International Colleges for Applied Medical Sciences,

Almadina Almonawarah Saudi Arabia. Permanent address, Ministry of Education, Egypt.

*Corresponding Author: ibrahim.mousa@gebri.usc.edu.eg

\section{ABSTRACT}

The conventional drinking water treatment plant is depending on coagulation as the main step. In semiarid countries, Quality of produced sludge is major challenges in terms of assessing its optimal operation and performance due to temperature and inappropriate technologies. We study the removal efficiencies of the different designed clarifiers fed with same water comparing to WHO environmental guidelines. According to the analysis of water produced from different clarifiers in El-Asher Water Treatment Plant, the water quality of one clarifier was better than other one. While, nitrate and total phosphate were recorded higher values according to low formation rate of sludge. Improper coagulant dosage is another probable cause production of high aluminum content sludge especially if the coagulant is not dosed optimally. This is depending on the clarifier design and operation and maintenance problems.

Keywords: drinking water; clarifier; sludge; aluminum; decant system.

\section{INTRODUCTION}

The rapid growth of population has exerted the demand of safe potable water, which requires exploration and developing of raw water resources, treatment facilities and distribution system. In order to meet the increasing demand, the production of drinking water from a water treatment plant (WTP) has to be increased (Mousa et al., 2012).

Surface water mainly from different resources carries complex contaminant mixtures (suspended, colloidal matters and micropollutants) that can cause serious problems (Baat et al., 2020). Therefore, certain kind of treatment is required, depending on the quality of available raw water and quality needed at the users end. The conventional WTP involve the process of prechlorination, coagulation, flocculation, sedimentation, filtration and final disinfection. During these treatment processes large quantity residues or wastes are generated known as water treatment sludge (WTS) and a typical WTP produces about 100,000 ton/year of sludge (Babatunde and Zhao, 2007)

Nowadays, numerous treatment approaches have been applied to control heavy metal and semimetal pollutants from WTS, including chemical precipitation, ion exchange, reverse osmosis, electrochemical treatment, membrane filtration, floatation and adsorption (Fu and Wang, 2011: Carolin et al., 2017). Although different approaches have their inherent advantages, the most recognized approach is adsorption Ahmed and 
Ahmaruzzaman (2016). On the other hand, it has been advocated that waterworks sludge could be a potential recyclable product, offering great commercial potential for reuse (Goldbold et al., 2003; Rensburg and Morgenthal, 2003).

Therefore, with a continual increase in the production of waterworks sludge certain at least for now and in line with the prevailing legislative and economic drives pointing toward waste avoidance and beneficial reuse of waste streams, a number of constructive attempts and research efforts have been made particularly in recent years to reuse waterworks sludge (WWS) in many beneficial ways (Moodley and Hughes, 2005). These include laboratory and full-scale attempts at using WWS as a component in the manufacture of several materials such as concrete, cement mortars, clay materials, and fired ceramic products (e.g., bricks, pipes, and tiles) (Goldbold et al., 2003); as geotechnical works materials (Skerratt and Anderson, 2003; Carvalho and Antas, 2005); as having potential for use in agriculture activities (Titshall and Hughes, 2005; Martin, 2016; Xiong et al., 2020)

Fundamentally, such approaches at beneficial reuses offer two distinct advantages, in terms of economic savings on overall treatment plant operation costs and environmental sustainability. However, unlike the case of sewage sludge, which has several papers and reviews on its beneficial reuse already published, it appears such a comprehensive review of beneficial reuses of waterworks sludge is lacking for now. Yet it is only a fraction on the scale of time before its generation complexes equal or greater attention from environmentalists, given our increasing human population and declining tolerance

The main objectives of this study were included examination the operation practices at the treatment plant. Also, it was aimed for obtaining information about the routine practices and their performance of Elasher drinking water treatment plant, Egypt. To assess the coagulation process of the water and the various process units aimed at establishing each unit's percentage reduction of different chemical and biological parameters in the water. This goes a way in determining each unit's performance in treating water comparing the water quality results with the Egyptian and WHO standard guidelines for drinking water to establish the treatment work's performance level.

\section{MATERIALS AND METHODS}

All chemicals used in this study were analytical grade. Deionized water (specific resistivity of $18.2 \mathrm{M} \Omega . \mathrm{cm}$ ) was obtained from a Veolia water system through filtering distilled water and was used in all the experiments.

\section{Water and sludge samples}

Water samples were collected from ElAsher city water treatment plant, Egypt, which has two different clarifier systems separately, one separated draining network specified for industrial sewage and the other is separate domestic network for normal use sewage drainage system. All testes were measured at $25^{\circ} \mathrm{C}$ according to requirements of standard methods (APHA, 2005). 


\section{Water analyses}

Water samples analyses were carried out as total dissolved solids (TDS) was determined experimentally according to ASTM D-1888. Conductivity was D-3301 according to ASTM D-1125. pH was determined experimentally according to ASTM D-1293. Total Alkaline species $\left(\mathrm{CO}_{3}, \mathrm{OH}\right.$, and $\left.\mathrm{HCO}_{3}\right)$ were determined

Sludge samples were mineralized with 65\% nitric acid (Merck, Germany) and Vanadium pentaoxide 98\% (Merck, analytical grade, Germany) (Hammad et al., 2016). Quantification of total aluminum in the influent, effluent and sludge was performed according to protocol of inductively couple plasma- Mass spectrophotometry (ICP-MS). Certified aluminum standard solution (1000 ppm) (Merck, Darmstadt, Germany) was used in order to prepare the working standard solutions ranged 10.0-1000.0 ppb.

\section{Statistical analysis}

The data were analyzed by using a statistical software (SPSS Version 17, SPSS INC, Chicago, IL, USA). Initially, the descriptive statistics were computed. One-way ANOVA was used followed by Duncan's post hoc test ( $\alpha$ 0.05). In all tests, $p$ values smaller than $5 \%$ were considered statistically significant.

\section{RESULTS AND DISCUSSION}

The WTP is of environmental concern and requires careful consideration if it is to be managed in an environmentally acceptable and sustainable manner. According to the analysis of WTP and its efficiency for different parameter were shown in Table (1) and Figure (1). The removal efficiencies of chemical parameters were ranged from +71.6 to $-30.9 \%$.

The sulfate was increased because additions of Alum sulfate as coagulant agent for sedimentation. However, the treatment removal\% of biological parameters was almost reached complete by using pre-chlorination and coagulation and sand filtration. Contrary, the sulfate was increased by about $30 \%$ through addition of alum sulfate for flocculation.

Table (1) Characterization of raw and potable water in average and SD and plant efficacies through fourteen months of studying period (Jan. 2019 - Feb. 2020).

\begin{tabular}{|c|c|c|c|c|}
\hline Parameters & unit & IN & out & Efficiency \\
\hline ammonia & $\mathrm{ppm}$ & $0.26 \pm 0.14$ & $0.11 \pm 0.06$ & $51.43 \pm 23.1$ \\
\hline Nitrite & $\mathrm{ppm}$ & $0.12 \pm 0.14$ & $0.03 \pm 0.04$ & $68.82 \pm 18.2$ \\
\hline Nitrate & $\mathrm{ppm}$ & $1.04 \pm 0.47$ & $0.76 \pm 0.40$ & $31.10 \pm 17.5$ \\
\hline Sulfate & $\mathrm{ppm}$ & $27.95 \pm 4.57$ & $36.3 \pm 4.7$ & $-30.92 \pm 9.3$ \\
\hline phosphate & $\mathrm{ppm}$ & $0.19 \pm 0.20$ & $0.05 \pm 0.06$ & $71.61 \pm 16.5$ \\
\hline Iron & $\mathrm{ppm}$ & $0.15 \pm 0.2$ & $0.045 \pm 0.0$ & $61.57 \pm 23.0$ \\
\hline Aluminum & $\mathrm{ppm}$ & $0.20 \pm 0.0$ & $0.15 \pm 0.0$ & $23.39 \pm 14.1$ \\
\hline Total fungi & $\mathrm{CFU} / \mathrm{l}$ & $6512 \pm 1255$ & $15 \pm 5.2$ & $99.8 \pm 0.1$ \\
\hline Total bacteria & $\mathrm{CFU} / \mathrm{ml}$ & $1195 \pm 348$ & $2 \pm 0.56$ & $99.8 \pm 0.05$ \\
\hline
\end{tabular}

The various treatment results indicate process while the $\mathrm{pH}$ conditions are relatively that turbidity decreases along the treatment constant throughout the treatment plant. The 
results also show an abnormality with the sulfate removal across the treatment process i.e. higher values at the tap water than at the intake water to the treatment plant (Mousa, El-

Rakshy., 2010)

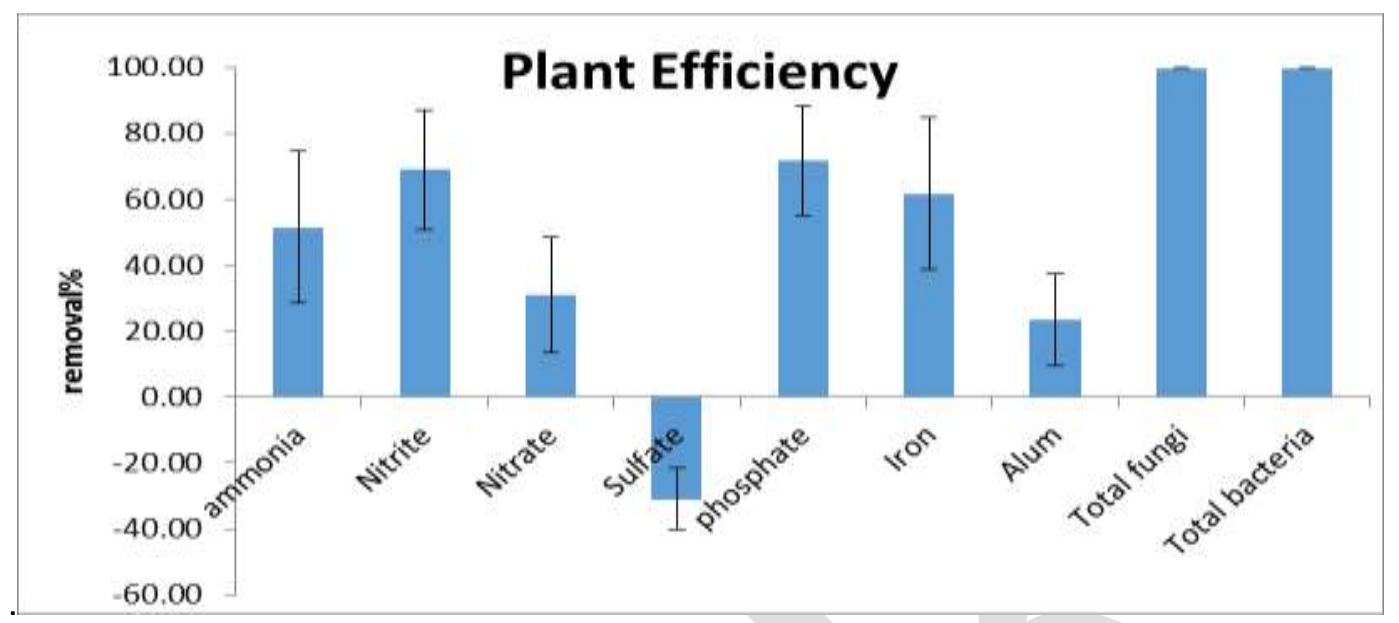

Figure (1) drinking water treatment plant efficiencies of chemical and biological parameter (average \pm SD)

\section{Characterization of water quality and} sludge of different clarifiers

According to the analysis of water produced from different clarifiers in El-Asher WTP in Table (2) and Figure (2), the water quality of clarifier \#3 was better than clarifier \#2. While, nitrate and total phosphate were recorded higher values according to low formation rate of sludge as shown in Table (3). The dried sludge's composition could be consider as a primary source of aluminum- and iron-based coagulants which go through several recovery process for phosphorus and iron reduction during wastewater treatment (Babatunde et al., 2005; Yang et al., 2006).

Table (2) chemical quality of water produced from different clarifiers.

\begin{tabular}{|c|c|c|c|}
\hline Parameter & Unit & clarifier (2) water & clarifier (3) water \\
\hline Ammonia $\left(\mathrm{NH}_{3}\right)$ & $\mathrm{mg} / \mathrm{L}$ & $2.22 \pm 2.29$ & $1.84 \pm 1.99$ \\
\hline Nitrate $\left(\mathrm{NO}_{3}\right)$ & $\mathrm{mg} / \mathrm{L}$ & $5.32 \pm 5.46$ & $5.65 \pm 6.11$ \\
\hline Total phosphates $\left(\mathrm{PO}_{4}\right)$ & $\mathrm{mg} / \mathrm{L}$ & $0.87 \pm 0.91$ & $1.16 \pm 1.26$ \\
\hline Aluminum $(\mathrm{Al})$ & $\mathrm{mg} / \mathrm{L}$ & $0.13 \pm 0.03$ & $0.08 \pm 0.08$ \\
\hline Total iron $(\mathrm{Fe})$ & $\mathrm{mg} / \mathrm{L}$ & $0.07 \pm 0.07$ & $0.04 \pm 0.04$ \\
\hline
\end{tabular}




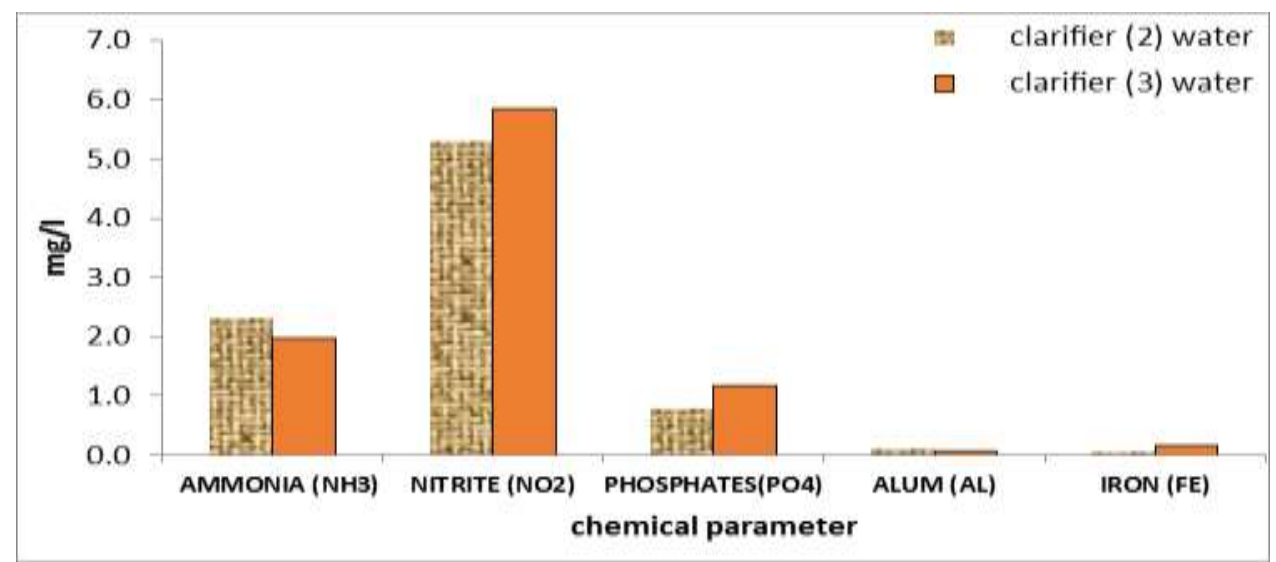

Figure (2) Comparison between different clarifiers water produced from El-Asher drinking Water

The main problem is the discharging of sludge or recycling. The Jar test done to obtain optimum coagulant dosage as well as $\mathrm{pH}$ for optimal coagulation are summarized in Figure 4.

\section{Rate and quantity of produced sludge}

In Table (3), show the sludge formation of the clarifiers in WTP. The quantity of sludge released from clarifier \#3 was generally lower than clarifier \#2 probably because of the design of clarifiers and the levels of suspended and dissolved solids washed time with the same surface water source. It is also evident that sludge levels reduce considerably along the sedimentation processes due to settlement of flocks formed during coagulation/flocculation process. treatment.

\section{Coagulation process has been} applied in drinking water treatment to decrease suspended particles, color and remove pathogens (Volk et al., 2000). The suspended matters removal by the filtration unit, however, stands at $30 \%$ of received water (Mousa et al., 2010). The increased suspended matters of the clarified water has a direct influence on the turbidity levels of the tap water as can be observed from the turbidity removal trend of the treatment units in WTP. The percentage suspended matters removal by the flocculation unit increases steadily from unit \#2 and this can be directly attributed to improved coagulant dosage and similar conclusion can be made of the sedimentation design.

Table (3) sludge formation weight collected from different clarifiers.

\begin{tabular}{|c|c|c|c|}
\hline Time $(\mathbf{m i n})$ & Unit & clarifier (2) sludge & clarifier (3) sludge \\
\hline $\mathbf{0}$ & $\mathrm{mg} / \mathrm{L}$ & $0.51 \pm 0.01$ & $0.92 \pm 0.11$ \\
\hline $\mathbf{2}$ & $\mathrm{mg} / \mathrm{L}$ & $0.74 \pm 0.06$ & $0.88 \pm 0.09$ \\
\hline $\mathbf{4}$ & $\mathrm{mg} / \mathrm{L}$ & $0.83 \pm 0.05$ & $0.83 \pm 0.07$ \\
\hline $\mathbf{6}$ & $\mathrm{mg} / \mathrm{L}$ & $1.61 \pm 0.15$ & $0.79 \pm 0.04$ \\
\hline $\mathbf{8}$ & $\mathrm{mg} / \mathrm{L}$ & $4.10 \pm 0.14$ & $0.72 \pm 0.05$ \\
\hline 10 & $\mathrm{mg} / \mathrm{L}$ & $1.10 \pm 0.28$ & $0.66 \pm 0.01$ \\
\hline 12 & $\mathrm{mg} / \mathrm{L}$ & $0.59 \pm 0.06$ & $0.60 \pm 0.00$ \\
\hline 15 & $\mathrm{mg} / \mathrm{L}$ & $0.28 \pm 0.04$ & $0.52 \pm 0.02$ \\
\hline 20 & $\mathrm{mg} / \mathrm{L}$ & $0.23 \pm 0.02$ & $0.33 \pm 0.01$ \\
\hline
\end{tabular}




\begin{tabular}{|c|c|c|c|}
\hline 25 & $\mathrm{mg} / \mathrm{L}$ & $0.17 \pm 0.01$ & $0.23 \pm 0.04$ \\
\hline 30 & $\mathrm{mg} / \mathrm{L}$ & $0.15 \pm 0.00$ & $0.15 \pm 0.04$ \\
\hline 35 & $\mathrm{mg} / \mathrm{L}$ & $0.13 \pm 0.00$ & $0.10 \pm 0.01$ \\
\hline Total & $\mathrm{mg} / \mathrm{L}$ & $\mathbf{1 0 . 6 0 \pm 0 . 0 1}$ & $\mathbf{6 . 8 4 \pm 0 . 0 1}$ \\
\hline
\end{tabular}

From the figure (3), it is evident that clarifier units have different sedimentation trends despite the fact that suspended matters should have been remarkable reduced by the sedimentation process. Another serious anomaly from this figure is that the clarifier sludge weight is constantly higher in the case of Clarifier \#2 and the quality for both the filtered water and the Tap water immediately after sedimentation have not effected.

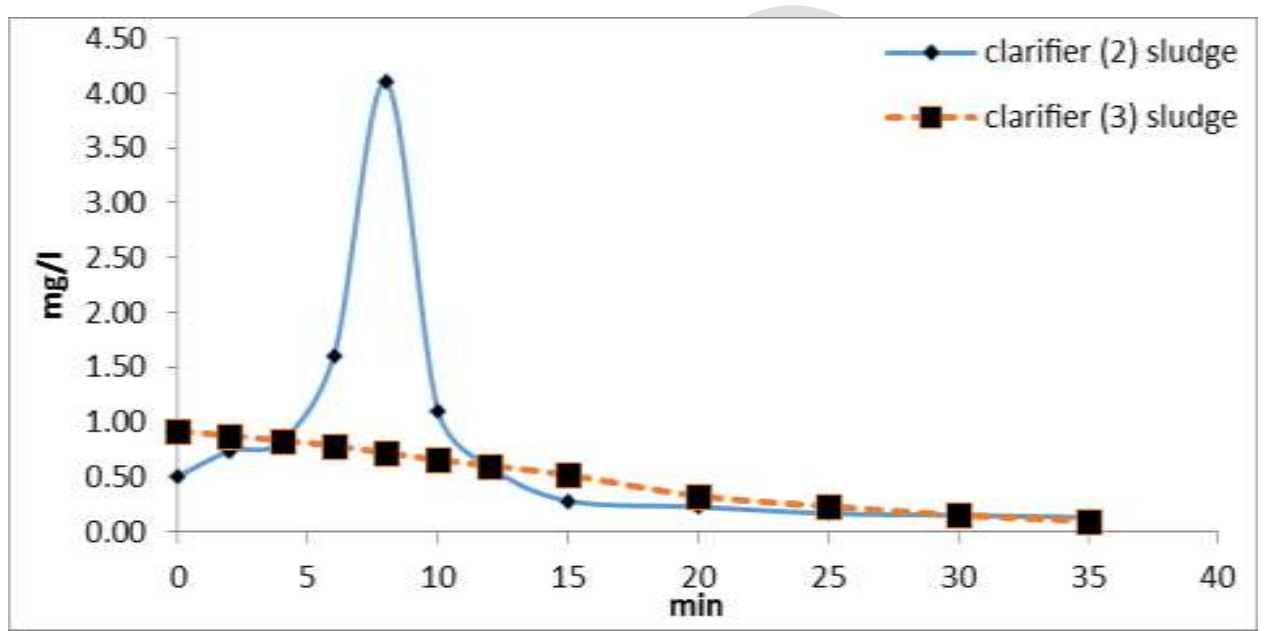

Figure (3) trends of sludge formation collected from different clarifiers across the time of released.

The summary of chemical quality of the potable water have averagely quality less clarifier water results as well as the recommended WHO standards for various water treatment process units is given in table than the WHO recommendations except total fungi of clarified water. Also, the tap waters have good quality.

4. The water immediately after clarifiers and

Table 4: clarified water quality results compared to WHO standards

\begin{tabular}{|c|c|c|c|c|c|}
\hline Parameters & unit & $\begin{array}{c}\text { Clarifier } \\
\text { water }\end{array}$ & $\begin{array}{c}\text { Potable } \\
\text { water }\end{array}$ & $\begin{array}{c}\text { WHO } \\
\text { standards }\end{array}$ & Comments \\
\hline ammonia & $\mathrm{ppm}$ & 2.03 & $0.11 \pm 0.06$ & 0.5 & within standards \\
\hline Nitrite & $\mathrm{ppm}$ & $\mathrm{ND}$ & $0.03 \pm 0.04$ & 0.2 & within standards \\
\hline Nitrate & $\mathrm{ppm}$ & 5.485 & $0.76 \pm 0.40$ & 45 & within standards \\
\hline Sulfate & $\mathrm{ppm}$ & $\mathrm{ND}$ & $36.3 \pm 4.7$ & 250 & within standards \\
\hline phosphate & $\mathrm{ppm}$ & 1.015 & $0.05 \pm 0.06$ & ---- & ---- \\
\hline Iron & $\mathrm{ppm}$ & 0.105 & $0.045 \pm 0.0$ & 0.3 & within standards \\
\hline Aluminum & $\mathrm{ppm}$ & 0.055 & $0.15 \pm 0.0$ & 0.2 & within standards \\
\hline Total bacteria & $\mathrm{CFU} / \mathrm{ml}$ & $\mathrm{ND}$ & $2.0 \pm 0.56$ & 5 & within standards \\
\hline
\end{tabular}

ND: not detected 


\section{CONCLUSION}

The WHO requirements of drinking water quality should have a certain values for the tap water. Different clarified water with treatment of pre-disinfection by chlorine and coagulation was assessed. This system that includes different designed clarifiers does not meet the WHO standards that need more filtration unit.

Without proper coagulation/ flocculation, the suspended particles do not form denser flocks which are able to settle in the sedimentation tanks. This therefore is a ripple effect since the treatment units are interrelated. It is evident that the problem is with the produced sludge as well as the decant

\section{ACKNOWLEDGEMENTS}

This study was funded by research supporting grant from Science and Technology Development Fund (STDF), project No. CB2741.

\section{REFERENCES}

Ahmed, M.J.K. Ahmaruzzaman, M. (2016) A review on potential usage of industrial waste materials for binding heavy metal ions from aqueous solutions, J. Water Process Eng. 10: 39-47, https://doi.org/10.1016/j.jwpe.2 016.01.014.

Baat, M.L. Van der Oost, R. Van der Lee, G.H. Wiering, N. Hamers, T. Verdonschot, P.F.M. De Voogt, d, P. Kraak, M.H.S. (2020) Advancements in effect-based surface water quality assessment. Water research 183, 116017 system. However, filtration units are fed with water from the sedimentation units and therefore without proper sedimentation of the flocks in the sedimentation process, the filter units are bound to be overloaded which can cause clogging of the filters.

Improper coagulant dosage is another probable cause production of high aluminum content sludge especially if the coagulant is not dosed optimally. This is depending on the clarifier design and operation and maintenance problems. 
results, In: Proceedings of the 10th European Conference on Biowastes and Biosolids Management, Yorkshire, UK,.

Carolin, C.F. Kumar, P.S. Saravanan, A. Joshiba, G.J. Naushad, M. (2017) Efficient techniques for the removal of toxic heavy metals from aquatic environment: a review, J. Environ. Chem. Eng. 5: 27822799,

https://doi.org/10.1016/j.jece.2 017.05. 029.

Carvalho, M., Antas, A. (2005) Drinking water sludge as a resource, In: Proceedings of IWA Specialised Conference on Management of Residues Emanating From Water and Wastewater Treatment, Johannesburg, South Africa.

Fu, F. Wang, Q. (2011) Removal of heavy metal ions from wastewaters: a review, J. Environ. Manage. 92:407-418, https://doi.org/10.1016/j.jenvm an.2010.11.011.

Goldbold, P., Lewin, K., Graham, A., Barker, P. (2003). The potential reuse of water utility products as secondary commercial materials. WRC technical report series, No UC 6081, project contract no.12420-0, Foundation for Water Research, UK.

Martin, C. (2016) From death comes life. Current biology 26 (13) R548 R552 https://doi.org/10.1016/j.cub.20 16.05.066.

Moodley, M., and Hughes J.C. (2005) The effects of a polyacrylamidederived water treatment residue on the hydraulic conductivity, water retention and evaporation of four contrasting South African soils and implications for land disposal, In: Proceedings of IWA Specialised Conference on Management of Residues Emanating From Water and Wastewater Treatment, Johannesburg, South Africa.

Mousa, I.E. Younes, K.H. El-Rakshy, N.A. Hassona, M.S. (2012) Improvement of noubaria canal water through biological aerated filtration system. Egypt. J. Exp. Biol. (Zool.) 8 (2) $161-169$.

Mousa, I.E., El-Rakshy, N.A. (2010) Assessment of Mahmoudia canal and drinking water nitrogen forms following some corrective actions. Journal of High Institute of Public Health 40, 24-40.

Rensburg, V.L., Morgenthal, T.L. (2003) Evaluation of water treatment sludge for ameliorating acid mine waste, J. Environ. Qual. 32, 1658-1668.

Skerratt, G., Anderson, M. (2003) A comparison of twelve waterworks sludge in England and the republic of Ireland with respect to their potential use in 
fired ceramic products, In:

Proceedings of the

International Symposium on

Recycling and Reuse of Waste

Materials, Dundee, Scotland.

Titshall, L.W., Hughes, J.C. (2005)

Characterization of some South African Water treatment residues and implications for land application, J. Water SA 31(3), 299-307.

Volk, C., Bell, K., Ibrahim, E., Verges, D., Amy, G., LeChevallier, M., 2000. Impact of enhanced and optimized coagulation on removal of organic matter and its biodegradable fraction in drinking water. Water Res. 34, 3247-3257.
Xiong, R. Yu, X. Zhang, Y.Peng, Z. Yu, L. Cheng, L. Li, T. (2020) Comparison of agricultural wastes and synthetic macromolecules as solid carbon source in treating low carbon nitrogen wastewater. Science of the total environment 739, 139885 https://doi.org/10.1016/j.scitote nv.2020.139885

Yang, Y., Zhao, Y.Q., Babatunde, A.O., Wang, L., Ren, Y.X., Han, Y. (2006) Characteristics and mechanisms of phosphate adsorption on dewatered alum sludge, Separation Purification Technol. 51(2), 193-200. 